\title{
INDUCED DEGRADATION OF CRUDE OIL POLLUTED SOIL BY MICROBIAL AUGMENTATION
}

\author{
SYLVESTER UWADIAE ${ }^{1 *}$, EMIKE OMOAYENA ${ }^{1}$ \\ ${ }^{1}$ Department of Chemical Engineering, University of Benin, PMB 1154, Benin City, Edo \\ State, Nigeria
}

\begin{abstract}
This study was aimed at assessing the effectiveness of indigenous microbes for remediation of hydrocarbon contaminated soil by first increasing the population of the indigenous microbes via bioaugmentation. Soil samples were treated using a consortium of bacteria: Bacillus substilis and Pseudomonas sp. which were isolated and cultured from the contaminated soil. The non-bacteria injected soil sample had the highest hydrocarbon content (THC) of 271.021 in comparison with the other soil samples. The THC percentage removal of B1 $(96.885 \%)$, B2 $(97.562 \%)$, B3 $(98.835 \%)$, B4 $(99.594 \%)$ and B5 $(99.540 \%)$ were higher than that of the control; indicating that biodegradation actually took place.
\end{abstract}

Keywords: bioremediation, bioaugmentation, bacteria, contaminated soil

\section{INTRODUCTION}

Developing countries heavily rely on crude oil and its fractions in various aspects of its society ranging from construction, transportation, power generation to various commercial activities since adequate alternative sources of energy are a long way off. It has been reported that since commercial exploration of petroleum started in Nigeria in 1958, petroleum has continuously grown to be a mainstay of the Nigerian economy [1]. Crude oil products are major soil contaminants. The exploitation of oil which includes drilling and production processes, refinery activities and accidental oil spills have a tremendous impact on the environment. Contamination of soils by crude oil remains an emerging issue. Equipment failure, human error, natural disasters and sabotage are some of the numerous factors responsible for oil spills. In Nigeria, oil spills have been a source of major concern, especially in the Niger Delta region. Oil spills on both land and water bodies have been on the increase with explorative and exploitative activities [2].

The major concern with crude oil spill has been its contamination of ground water, and the subsequent clean up [3]. Pollution is the major problem linked with crude oil exploration and exploitation and all aspects of the environment are grossly affected. Characteristics of soil are changed by crude oil contamination, polluting it at the expense of living organisms. Vegetation, wildlife, crops and farmlands are adversely affected [4].

A host of technologies have been developed and tested, since the contamination of soil and groundwater by crude oil spills has become a significant problem. These include physical (vapour extraction, solidification, spray, stabilisation), chemical (photo-oxidation, dissolution, use of detergent), and biological methods (bioremediation).Both physical and chemical methods do not provide complete removal of oil contaminants. The chemical technique involves the use of expensive chemical dispersants, which bring about more pollution thereby defeating the aim of the clean-up.

\footnotetext{
* Corresponding author, email: sylvester.uwadiae@uniben.edu

(C) 2017 Alma Mater Publishing House
} 
Bioremediation is any process that involves the use of microorganisms, plants or their enzymes to restore the natural environment to its original state after an alteration by contaminants. The basic idea is to accelerate the rate of natural hydrocarbon degradation. Bioremediation effectiveness relies upon the physical and chemical conditions coupled with correct analysis of parent microbial population and environment condition [5]. Bioremediation has several potential advantages over conventional technologies, such as being less costly, less intrusive to the contaminated site, and more environmentally benign in terms of its end products [6]. Bioaugmentation is defined as the addition of microorganism, indigenous or exogenous to a contaminated site [7]. In Nigeria, there is a dearth of information on the commercial production of fungi or microbial inoculum for use in bioremediation of oil polluted environments [8].

\section{MATERIALS AND METHODS}

\subsection{Sampling}

Contaminated soil samples were collected from the Right-Of-Way of Petroleum Pipeline and Products Marketing Company (PPMC system 2C Pipeline) at Ugo Ikobi, Orhionmwon LGA in Edo state. Spill point Coordinates: N $06^{\circ} 02^{\prime} 29.6^{\prime \prime}$; E $005^{\circ} 56^{\prime} 35.0^{\prime \prime}$. The samples were collected at random points within the contaminated area. A handheld auger borer was used to collect the soil samples at different depths of $0-15 \mathrm{~cm}$, 15-30 cm and 30-45 cm. For each depth, 2 samples were taken and all the samples from each depth were mixed to form a composite sample. They were collected in sterile polythene bags, labelled appropriately and taken immediately to the laboratory where they were sieved using a $4 \mathrm{~mm}$ sieve mesh. The samples were stored at $-2{ }^{\circ} \mathrm{C}$ in a refrigerator before analysis.

\subsection{Enumeration of microbial populations}

Ten (10) grams of the oil-contaminated soil were suspended in $90 \mathrm{~mL}$ of distilled water and tenfold serial dilutions of the soil samples from 1:10 to 1:100000 were carried out. $0.1 \mathrm{~mL}$ of the $10^{-5}$ dilution for each soil samples were plated in triplicate on Nutrient agar amended with nystatin to suppress the growth of fungi and potato dextrose agar amended with streptomycin to inhibit the growth of bacteria using pour plate methods. The nutrient agar plates were incubated at $37{ }^{\circ} \mathrm{C}$ for $24-48$ hours while the potato dextrose agar plates were incubated (New Brunswick Scientific G-27 PsycroTherm) at $28 \pm 2{ }^{\circ} \mathrm{C}$ for 72 hours in line with previous studies [9]. The number of viable micro-organisms in the sample was calculated from the number of colonies formed and the volume of inoculums and the dilution factor were expressed in colony forming unit.

\subsection{Isolation of colonies from contaminated soil}

One gram of contaminated soil was placed in a test tube and serially diluted using a $9 \mathrm{~mL}$ physiological saline solution $(0.85 \% \mathrm{NaCl})$. Then $0.2 \mathrm{~mL}$ of the $10^{-2}, \mathrm{I}^{-3} 10^{-4}$ and $10^{-5}$ dilutions were spread on plates that were previously prepared from trypticase soya agar (TSA). The plates were put in an incubator at $25{ }^{\circ} \mathrm{C}$ under aerobic conditions for 48 hours. Specific colonies were isolated and subcultured onto TSA plates and incubated for another 48 hours. Plates were then put in a refrigerator at $4^{\circ} \mathrm{C}$ for further study and identification.

\subsection{Identification of colonies by Gram Stain technique}

Bacterial cells are difficult to observe because they are nearly transparent. However, most bacteria can be stained by dyes to increase the contrast between the cells and the background. The Gram Stain technique was used on the colonies of microorganism. One smear of each colony was prepared on a glass slide. The smear was stained with crystal violet solution for one minute then washed off with Gram's iodine. The Gram's iodine solution was left on the smear for one minute, then it was washed with water and drained. The smear was decolorized with alcohol $(95 \%)$ until free of colour (approximately 30 seconds), and the slide was washed with water and drained. The smear was flooded with safranin for 30 seconds, then washed and blotted dry by placing the slide between two clean pages of paper. The shapes of the cells were then observed through a microscope.

\subsection{Enrichment of bacterial cultures}

The enrichment of the cultures was carried out in a $1 \mathrm{~L}$ glass jar. One tiny bit of each colony was taken from a TSA plate and suspended in separate glass jars containing $450 \mathrm{~mL}$ distilled water. Each colony was inoculated into separate $1 \mathrm{~L}$ flasks. The jars were left at room temperature for 48 hours.

\subsection{Set up of the close system reactors and test procedures}

Closed system reactors were built in $2000 \mathrm{~mL}$ total volume plastic bowls with tight lids and labelled B1, B2, B3, B4, B5 (Table 1). $450 \mathrm{~g}$ of the contaminated soil was weighed and transferred to each of the sterilized plastic 
bowls. $40 \mathrm{~mL}$ mixed consortia of Pseudomonas sp. and Bacillus substilis were seeded into the plastic bowls and mixed to increase the population of bacteria in order to enhance the rate of bioremediation. After mixing, the reactors were kept away from sunlight at room temperature to prevent dehydration. The soil was mixed every week in order to supply oxygen to microorganisms for a 42 day period. $20 \mathrm{~mL}$ of distilled water was added weekly to keep the soil moist. Microbial analysis was carried out every fortnight to count bacteria. Samples were taken at the beginning and end of the 42 day period to analyse the Total Hydrocarbon Content (THC).

\subsection{Preparation of the control}

\subsubsection{Control Al}

Autoclaved soil was used to prepare a control reactor. The contaminated soil was put into a $250 \mathrm{~mL}$ conical flask. Foil paper was used to seal the conical flask to avoid contamination. The glass jar was left in the autoclave for half an hour at $121{ }^{\circ} \mathrm{C}$ and $0.0043 \mathrm{~kg} / \mathrm{m}^{2}\left(15 \mathrm{lb} / \mathrm{in}^{2}\right)$. After that, the glass jar was left in the laboratory overnight. The same autoclave procedure was repeated the next day. The autoclaved sample was kept in the refrigerator throughout the duration of the experiment. When samples were required, they were taken and analysed under aseptic conditions.

\subsubsection{Control A2}

$450 \mathrm{~g}$ of contaminated soil was placed in a $2000 \mathrm{~mL}$ total volume plastic bowl with a tight lid (Table 1).

Table 1. Composition of various treatment options.

\begin{tabular}{|c|c|c|c|l|}
\hline Closed Reactor & Identity & Composition/matrix & $\mathrm{pH}$ & Amendment \\
\hline 1 & A1 & Autoclaved soil & 5.1 & - \\
\hline 2 & A2 & CS & 5.1 & Water \\
\hline 3 & B1 & CS & 3 & MO + Water \\
\hline 4 & B2 & CS & 5 & MO + Water \\
\hline 5 & B3 & CS & 7 & MO + Water \\
\hline 6 & B4 & CS & 9 & MO + Water \\
\hline 7 & B5 & CS & 11 & MO + Water \\
\hline
\end{tabular}

*MO-Microorganism; *CS-Contaminated soil.

\subsection{Analytical Methods}

During the bioremediation, selected parameters was monitored the following parameters: $\mathrm{pH}$, dry matter content, moisture content, conductivity, total organic carbon/organic matter content, total hydrocarbon content (THC), total heterotrophic bacteria count, total heterotrophic fungi count, total bacteria count was measured using standard procedures reported elsewhere [10].

\section{RESULTS AND DISCUSSION}

The results for the physicochemical properties of the soil for bioremediation are detailed in Table 2 .

Table 2. Physicochemical characteristics of soil samples.

\begin{tabular}{|l|c|}
\hline \multicolumn{1}{|c|}{ Parameter } & Type/Value \\
\hline $\mathrm{pH}$ & 5.1 \\
\hline Soil Texture & Fine to medium coarse sand \\
\hline Soil Moisture content $(\%)$ & 9.22 \\
\hline Dry matter content $(\%)$ & 97.54 \\
\hline Total Organic Carbon $($ TOC) $(\%)$ & 1.08 \\
\hline Organic matter $(\%)$ & 1.86 \\
\hline Electrical Conductivity $(\mu \mathrm{S} / \mathrm{cm})$ & 530 \\
\hline
\end{tabular}

From the results presented in Table 2, the soil texture was found to be of fine to medium coarse sand. Permeable soils, such as sands and gravels, are more favourable to the transport of nutrients, water and oxygen to the area of bioactivity. This soil type is consistent for effective bioremediation because of its low clay and silt contents [11]. The moisture content of soil sample was $9.22 \%$. When moisture content is lower than $10 \%$ of the holding capacity, the bioactivity becomes marginal [12]. For optimum growth and proliferation, microorganisms require 
$12 \%$ to $25 \%$ of moisture [13]. The initial soil $\mathrm{pH}$ value used for the bioremediation was very acidic in nature (5.1). The soil $\mathrm{pH}$ is below the optimum value of 6-8 for biodegradation of hydrocarbons. Soil $\mathrm{pH}$ is important because most microbial species can survive only within a certain $\mathrm{pH}$ range. Furthermore, soil $\mathrm{pH}$ can affect availability of nutrients. The soil has a medium total organic carbon (TOC) percentage since its value was $1.08 \%$. One of the most important soil parameters influencing the effectiveness of bioaugmentation is organic matter. Soil organic matter (SOM) is a reservoir of carbon and plant nutrients. It plays a role in bioavailability of pollutants and inhibits the survival of inoculated strains and their contaminant degrading capabilities. From a related study [14], SOM increased significantly after an oil contamination. Many studies have shown that there is a close correlation between soil organic matter and Petroleum hydrocarbon bioavailability to plants. The dry matter content is an indication of the moisture condition which is determined mainly by the weather, soil texture and geological conditions. The electrical conductivity (EC) represents the concentration of ions in the soil. A high level of electrical conductivity indicates a high concentration of dissolved salt ions in the soil samples. The electrical conductivity was $530 \mu \mathrm{S} / \mathrm{cm}$ and this represents the ratio of soil salinity. This EC value translates to $0.53 \mathrm{dS} / \mathrm{m}(<2 \mathrm{dS} / \mathrm{m})$ which indicates that the soil sample is non saline. This class of salinity has negligible effects on crop plants.

The total hydrocarbon utilizing bacteria count results are shown in Table 3.

Table 3. Total hydrocarbon utilizing bacteria (HUB) count (colony forming units/g soil).

\begin{tabular}{|c|c|c|c|c|c|c|c|}
\hline \multirow{2}{*}{$\begin{array}{c}\text { Bioremediation } \\
\text { time(days) }\end{array}$} & \multirow{2}{*}{$\begin{array}{c}\text { Control } \\
\text { 1,A1 }\end{array}$} & \multirow{2}{*}{$\begin{array}{c}\text { Control } \\
2, \mathrm{~A} 2 \\
\text { (cfu/g soil) }\end{array}$} & \multicolumn{5}{|c|}{ Total bacteria count(cfu/g soil) } \\
\cline { 4 - 8 } & cfu/g soil) & B1 & B2 & B3 & B4 & B5 \\
\hline 1 & $4.4 \times 10^{8}$ & $4.4 \times 10^{8}$ & $4.4 \times 10^{8}$ & $4.4 \times 10^{8}$ & $4.4 \times 10^{8}$ & $4.4 \times 10^{8}$ & $4.4 \times 10^{8}$ \\
\hline 14 & 0 & $4 \times 10^{6}$ & $4 \times 10^{2}$ & $5.2 \times 10^{6}$ & $2.4 \times 10^{6}$ & $4 \times 10^{6}$ & $1.4 \times 10^{8}$ \\
\hline 28 & 0 & $2 \times 10^{4}$ & 0 & $1.5 \times 10^{4}$ & $3 \times 10^{5}$ & $3 \times 10^{3}$ & $5 \times 10^{5}$ \\
\hline 42 & 0 & $3 \times 10^{4}$ & 0 & $3 \times 10^{6}$ & $1.2 \times 10^{5}$ & $1.3 \times 10^{4}$ & $1.2 \times 10^{6}$ \\
\hline
\end{tabular}

Crude oil was relied on as a carbon source in estimating the activity of the petroleum degrading microbial population. Microorganisms play a major role in bioremediation and their absolute number can determine the overall degradation ability [15]. Microorganism's activity was monitored by bacteria counting. The populations of bacteria in control 1-autoclave soil, control 2-non-bacteria injected soil, and bacteria injected soil were counted at day one of the bioremediation process, and subsequently at 14, 28 and 42 days to evaluate the changes in bacteria population. The hydrocarbon utilizing bacteria and fungi identified in the course of this research include: Bacillus substilis, Pseudomonas sp., Aspergillus niger, Staphylococcus sp, Penicillium notatum. Based on their capabilities to grow on crude oil and individual hydrocarbons as their sole carbon source, a consortia of bacteria were used. As explained elsewhere [16], no single species of microorganism is capable of degrading the many different hydrocarbon components in oil products. Thus many different enzymes and metabolic pathways are required to degrade the significant number of compounds contained in petroleum and related products. In a previous study [17]. Bacillus sp. was reported as being the predominant isolate of all the crude oil utilizing bacteria characterized from highly polluted soil samples (30\% and $40 \%$ crude oil). It was postulated that Bacillus species are more tolerant to high levels of hydrocarbons in soil due to their resistant endospores.

Before adding the consortia of bacteria, the Total heterotrophic bacteria count (THBC) and the total heterotrophic fungi counts (THFC) were $4.4 \times 10^{8} \mathrm{cfu} / \mathrm{g}$ and $1.6 \times 10^{3} \mathrm{cfu} / \mathrm{g}$ respectively. The microbial numbers continued to decrease from the time of inoculation up to 42 days when the study was terminated. The bacterial cell counts remained lower than the initial THBC. For reactor B1, the CFU counts decreased from $4.4 \times 10^{8} \mathrm{cfu} / \mathrm{g}$ soil to $4 \times 10^{2} \mathrm{cfu} / \mathrm{g}$ at 14 days and subsequently decreased to $0 \mathrm{cfu} / \mathrm{g}$ for the remaining period of the study. This supports the report that most bacteria have a low tolerance for acidic conditions [18]. For reactor B2, bacterial count decreased to $5.2 \times 10^{6} \mathrm{cfu} / \mathrm{g}$ in 14 days and further decreased to $1.5 \times 10^{4} \mathrm{cfu} / \mathrm{g}$ in 28 days, although an increase was noticed 14 days later. Counts gradually decreased to $2.4 \times 10^{6} \mathrm{cfu} / \mathrm{g}$ soil within 14 days and fluctuated between $3 \times 10^{5} \mathrm{cfu} / \mathrm{g}$ and $1.2 \times 10^{5} \mathrm{cfu} / \mathrm{g}$ for 42 days in reactor B3. For reactor B4, total bacterial count decreased to $4 \times 10^{6} \mathrm{cfu} / \mathrm{g}$ soil at 14 days and steadily declined to $3 \times 10^{3} \mathrm{cfu} / \mathrm{g}$ in 28 days. In 42 days, the count had increased to $1.3 \times 10^{4} \mathrm{cfu} / \mathrm{g}$. For reactor B5, the CFU counts decreased to $1.4 \times 10^{8} \mathrm{cfu} / \mathrm{g}$ soil in 14 days and further decreased to $5 \times 10^{5} \mathrm{cfu} / \mathrm{g}$ after 28 days. At the end of the 42 day period, an increase of $1.2 \times 10^{6} \mathrm{cfu} / \mathrm{g}$ in the bacterial count was noted. The drop in bacteria counts level in the soil within the study period can be attributed to selective inhibition of microorganisms as a result of the toxic components of petroleum and also as a result of reduced degradation and upsets in carbon/inorganic nutrient balance for the indigenous population caused by the presence of petroleum. The concentration of hydrocarbon can affect bioactivity and be toxic to the 
microorganisms [19]. The decline in population of HUB counts from day 1 to 42 may be due to nutrient exhaustion with possible accumulation of toxic metabolites in the media, which marked the on-set of stationary and death phases. When biodegradation is carried out under alkaline conditions, there is a gap between the native soil living conditions and the alkali environment, which prevents optimal growth of bacteria. This is observed for pH 9 and 11 as there was a decline in microbial populations. For reactor A1 (autoclaved sample), there was no microbial activity as all microorganisms had been destroyed by high temperature and it was stored at a very low temperature. For the soil without any microbial consortia added (reactor A2), the cell counts dropped from $4 \times 10^{6} \mathrm{cfu} / \mathrm{g}$ soil at 14 days to $2 \times 10^{4} \mathrm{cfu} / \mathrm{g}$ at 28 days and increased to $3 \times 10^{4} \mathrm{cfu} / \mathrm{g}$ after 42 days. It was observed that the microorganisms were trying to adapt and grow at the end of the study period. The results shown in Table 3 corroborated the reports of a previous related study [20] which showed that for successful biodegradation, the CFU count is not to be less than $10^{3}$ per gram soil. Therefore, from the study, biodegradation was successful. Table 4 shows the THC reduction achieved in the various closed reactors with the different amendments.

Table 4. THC reduction (\%) obtained in the different samples.

\begin{tabular}{|c|l|c|}
\hline \multicolumn{1}{|c|}{ Closed reactor } & \multicolumn{1}{|c|}{ Amendment } & THC reduction (\%) \\
\hline Control 2(A2) & Water & 91.008 \\
\hline B1 & MO+ Water & 96.885 \\
\hline B2 & MO+ Water & 97.562 \\
\hline B3 & MO+ Water & 98.835 \\
\hline B4 & MO+ Water & 99.594 \\
\hline B5 & MO+ Water & 99.540 \\
\hline
\end{tabular}

*MO- Microorganism

It was observed that the highest percentage removal occurred in both reactors B4 and B5 with percentage reduction of $99.594 \%$ and $99.540 \%$ respectively. The control (A2) showed the least percentage removal with percentage reduction of 91.008 . The THC percentage removal of B1 (96.885 \%), B2 (97.562\%), B3 (98.835\%), B4 $(99.594 \%)$ and B5 $(99.540 \%)$ were higher than that of the control (A2); indicating that biodegradation actually took place. There was a high removal efficiency of THC, which indicates that the contaminated soil provides an appropriated environment for bacterial growth.

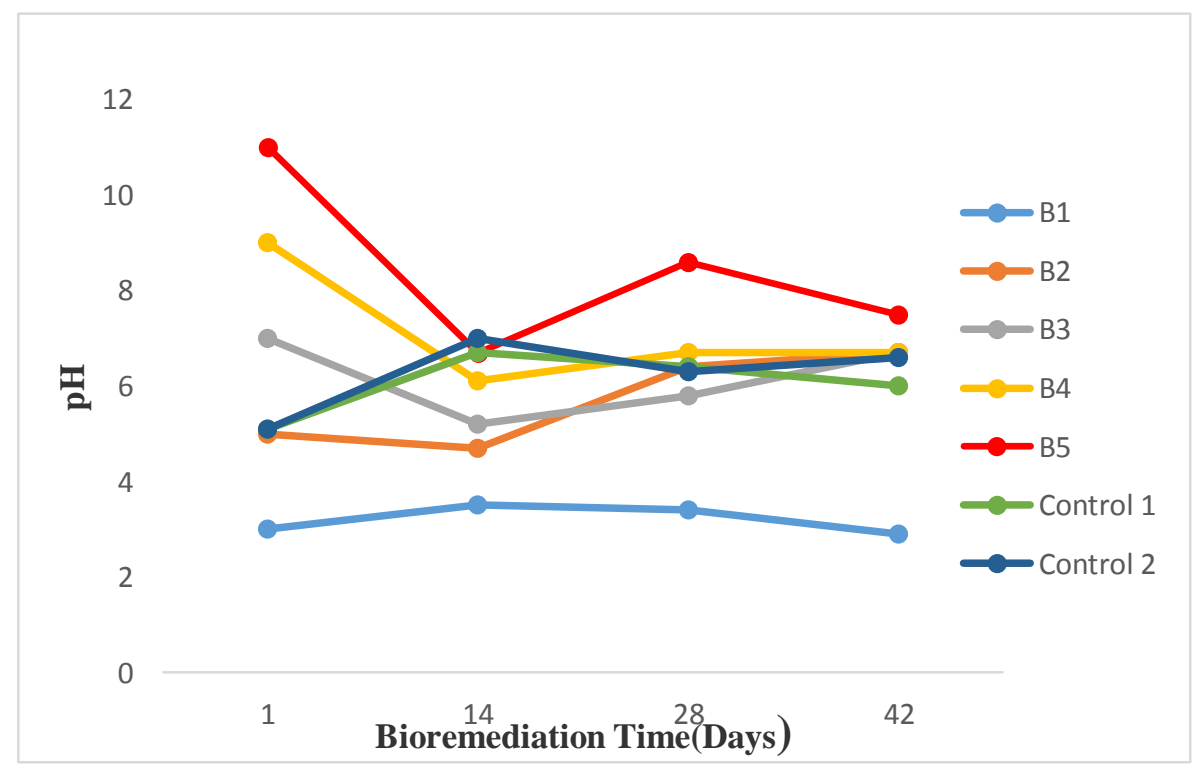

Fig. 1. Variation of $\mathrm{pH}$ with bioremediation Time.

The $\mathrm{pH}$ of the soil determines the type of microorganism present during hydrocarbon degradation. The $\mathrm{pH}$ of the soil was monitored and the results revealed that the $\mathrm{pH}$ of the crude oil contaminated soil amended with a consortium of bacteria ranged from 2.9 to 8.6. Results showing the variation of $\mathrm{pH}$ with remediation time are presented in Figure 1. Reactor B1 with soil sample that was highly acidic (3), had a slight rise in $\mathrm{pH}$ of 3.5 and 3.4 at 14 days and 28 days respectively. At the end of the bioremediation period of 42 days it had the least $\mathrm{pH}$ of 
2.9 (very acidic) in comparison with soil samples in the other reactors. As for reactor B2, its initial pH was very acidic (5), it declined to 4.7 (still very acidic) and rose sharply to 6.7 (faintly acidic). This is in agreement with findings in a previous study [21] that an increase in $\mathrm{pH}$ suggests the release of by-products during hydrocarbon degradation. For reactor $\mathrm{B} 3$, initial $\mathrm{pH}(7)$ was neutral and this value falls into the $\mathrm{pH}$ range reported by in a previous study [16] for optimum microbial growth (5.5-8.8) and hydrocarbon biodegradation (6.5-8.0). After 14 days its $\mathrm{pH}$ dropped to 5.2 (very acidic), thereafter, rose slightly to 5.8 (distinctly acidic) at 28 days and steadily climbed to 6.7 (faintly acidic) at the end of the treatment period. This trend could be attributed to acidic metabolites resulting from hydrocarbon degradation. For Reactor B4, its initial pH was 9 (extremely alkaline) and it dropped sharply to 6.1 after 14 days and rose steadily to 6.7 (faintly acidic) at 28 days and remained constant till the end of the remediation period. The sharp decrease could be due to the production of carboxylic acids during degradation process [22]. The steady rise to 6.7 suggests the release of by-products during hydrocarbon degradation as shown elsewhere [23]. For reactor B5 with initial pH of 11 (extremely alkaline), its $\mathrm{pH}$ dropped sharply to 6.7 (faintly acidic) at 14 days and rose again to 8.6 (extremely alkaline) at 28 days and finally dipped to 7.5 (faintly alkaline) at 42 days. The decrease in $\mathrm{pH}$ was believed to be due to the production of microbial metabolites which resulted in decrease in $\mathrm{pH}$ as the microorganisms utilize the substrate. Microbial degradation of xenobiotic compounds has been reported to result in alteration of $\mathrm{pH}$ in soil and aquatic media [24]. As pH of the soil falls below 6, the availability of Nitrogen, Phosphorus and Potassium becomes restricted. To evaluate the effect of the number of microorganisms on the degradation of TPH, the results obtained for the 42 day study period from non-bacteria injected soil were compared to that obtained from bacteria injected soil. The results are presented in Figure 2.

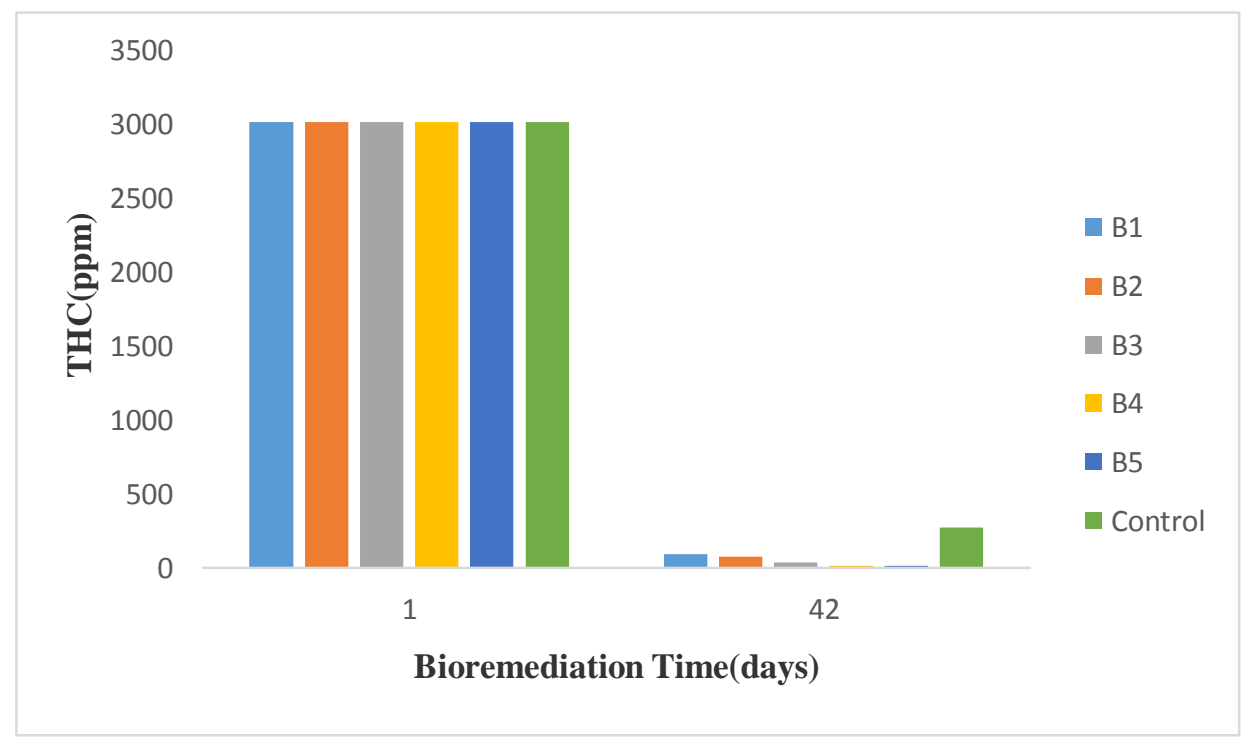

Fig. 2. Variation of total hydrocarbon content (THC) with bioremediation time.

Based on the THC analysis, the crude oil compound degraded rapidly under all conditions. Figure 2 showed that, the concentration of THC in the five reactors had a decreasing trend with increasing bioremediation time, which was consistent with the general degradation principle. Reactor B1 had the highest THC concentration of $93.878 \mathrm{ppm}$ and Reactor B4 had the least concentration of THC of $12.245 \mathrm{ppm}$ for the bioremediation period. This is in agreement with the report of Atlas (1984), that oil degrading microbes increases the rate of microbial metabolism of crude oil in the soil. The addition of the mixed consortia resulted in a significant degradation of the total hydrocarbon content (THC) of the soil compared with to the soil that was not supplemented by any microbial consortium. The findings of this study support the growing evidence that isolates belonging to the Bacillus substilis could be elective in clearing oil spills. It would also be important to note that there was also a significant reduction in THC for the soil that was not supplemented by a microbial consortium (A2) as a result of natural attenuation and action of the indigenous microbial population of the polluted soil. The most significant reduction was seen in the soil with a $\mathrm{pH}$ of 9 . This is an indication that the extreme alkalinity of the soil favored the growth and activity of the bacteria. This also supports the report in a related study that biodegradation is higher under slightly alkaline than under acidic conditions [25]. These results indicate that inoculating indigenous microorganism is an effective method for bioremediation of crude oil in soil. Cultures which were 
isolated from this contaminated soil have lived in a very acidic condition for a long time and have adapted to this environment. Therefore when biodegradation tests were conducted under acidic, alkaline and neutral conditions, significant hydrocarbon removal was observed. In Comparison, the THC reduction in the reactors amended with the microbial consortia were higher than that of the reactor not supplemented by a microbial consortia (Control A2). This indicates that the number of indigenous microbes were not as efficient in degrading oil and that the inoculation of the microbial consortia shows potential in removing hydrocarbon contaminants.

\section{CONCLUSIONS}

It could be observed from the current study that Reactor B1 with $\mathrm{pH}$ of 3 had the highest THC concentration of $93.878 \mathrm{ppm}$ and Reactor B4 with $\mathrm{pH}$ of 9 had the least concentration of THC of $12.245 \mathrm{ppm}$ for the bioremediation period. The non-bacteria injected soil sample (Control 2) had the highest hydrocarbon content (THC) of 271.021 in comparison with the other soil samples. This clearly demonstrates the effectiveness of bioaugmentation over natural attenuation. Thus, the best bioaugmentation performance can be approached by the use of microorganisms that are already present in the soil and increasing their abundance.

The study demonstrated the potential of the mixed consortia of Pseudomonas sp. and Bacillus substilis in enhancing the population of indigenous microorganisms in the soil which in turn increases the biodegradation rate of crude oil in soil. This study also indicated that different factors come into play to determine the biodegradability of crude oil. The postulation that bioaugmentation achieves clean-up of polluted site within a very short time frame is supported by the findings of this study. The results of controlled experiments with environmental samples closely resemble what is obtainable in situ. However, it might be inaccurate to deduce the rate of biodegradability observed in this study to what can be obtained in a field situation.

\section{REFERENCES}

[1] Eneje, R.C., Nwagbara, C., Uwumarongie-Ilori, E.G., Amelioration of chemical properties of crude oil contaminated soil using compost from Calapoigonium mucunoides and poultry manure, International Research Journal of Agricultural Science and Soil Science, vol. 2, no. 6, 2012, p. 246-251.

[2] Ikhimiukor, O.O., Nneji, L.M., The review of the use of microorganisms in the biodegradation of crude oil spill, Researcher, vol. 5, no. 12, 2013, p. 155-163.

[3] Onwurah, I. N. E., Ogugua, V. N., Onyike, N. B., Ochonogor, A. E.' Otitoju, O. F., Crude Oil Spills in the Environment, Effects and Some Innovative Clean-up Biotechnologies, International Journal of Environmental Research, vol. 1, no. 4, 2007, p. 307-320.

[4] Okecha, S.P., Pollution and conservation of Nigeria's environment, T'Afrique International, Pollution and conservation of Nigeria's environment, vol. 1, 2000, p. 33-42.

[5] Nedwell, D.B., Effect of low temperature on microbial growth, FEMS Microbiology Reviews, vol. 30, 1999, p. 101-111.

[6] Okoh, A.I., Biodegradation of Bonny light crude oil in soil microcosm by some bacteria strains isolated from crude oil flow stations saver pits in Nigeria, African Journal of Biotechnology, vol. 2, no. 5, 2003, p. 104-108.

[7] Lahel, A., Fanta, A.B., Sergienko, N., Shakya, M., Lopez, M.E., Behera, S.K., Park, H., Effect of process parameters on the bioremediation of diesel contaminated soil by mixed microbial consortia International Biodeterioration and Biodegradation, vol. 113, 2016, p. 375-385.

[8] Huesemann, M.H., Truex, M.J., The Role of oxygen diffusion in passive bioremediation of petroleum contaminated soil, Journal of Hazardous Materials, vol. 51, 1996, p. 93-113.

[9] Ekhaise, F.O., Nkwelle, J., Microbiological and physicochemical analyses of oil contaminated soil from major motor mechanic workshops in Benin City metropolis, Edo State Nigeria. Journal of Applied Sciences and Environmental Management, vol. 154, 2011, p. 597 - 600.

[10] Black, C.A., Methods of soil analysis. Part I, American Society of Agronomy, Madison, Wisconsin, USA, 1965.

[11] Abdel-Moghny, T., Mohamed, S.A.R., El-Sayed, E., Aly, S.M., Snousy, M.G., Effects of soil texture on remediation, Chemical Engineering, vol. 19, 2012, p. 1-13.

[12] Pezeshki, S.R., Hester, M.W., Lin, Q., Nyman, J.A., The effects of oil spill and clean-up on dominant US Gulf coast marsh macrophytes: a review, Environmental Pollution, vol. 108, no. 2, 2000, p. 129-139. 
[13] Mukherjee, A.K., Das, K., Correlation between diverse cyclic lipopeptides production and regulation of growth and substrate utilization by Bacillus subtilis strains in a particular habitat. FEMS Microbiology Ecology, vol. 54, 2005, p. 479-489.

[14] Liu, W.X., Luo, Y.M., Teng, Y., Li, Z.G., Wu, L.H., The initial research on the petroleum contamination in oilfields and oily sludge in China, Soils, vol. 39, no. 2, 2007, p. 247-251.

[15] Adeyinka, J.S., Urum, K.C.N., Assessment and determination of bioremediation efficiency in a post crude oil pollution treatment, Tropical Environmental Research, vol. 3, 2001, p.181-187.

[16] Sihag, S., Pathak, H., Jaroli, D.P., Factors affecting the rate of biodegradation of polyaromatic hydrocarbons, International Journal of Pure \& Applied Bioscience, vol. 2, no. 3, 2014, p. 185-202.

[17] Ijah, U.J.J., Antai, S.P., Removal of Nigerian light crude oil in soil over a 12-month period, International Biodeterioration and Biodegradation, vol. 51, 2003, p. 93-99.

[18] Nasseri, S., Kalantary, R.R. Nourieh, N., Naddafi, K., Mahvi, A.H., Baradaran, N., Influence of bioaugmentation in biodegradation of PAHs-contaminated soil in a bio-slurry phase reactor, Iranian Journal of Environmental Health Science \& Engineering, vol.7, no. 3, 2010, p. 199-208.

[19] Hentati, O. Lachhab, R. Ayadi, M., Ksibi, M., Toxicity assessment for petroleum-contaminated soil using terrestrial invertebrates and plant bio assays, Environmental Monitoring and Assessment, vol. 185, 2013, p. 2989-2998.

[20] Margesin, R., Labbe, D., Schninner, F., Greer, C.W., Whyte, L.G., Characterisation of hydrocarbon degrading microbial populations in contaminated and pristine contaminated soils, Applied and Environmental Microbiology, vol. 69, no. 6, 2003, p. 3985-3092.

[21] Rahman, R.N, Baharum, S.N., Basri, M., Salleh, A.B., High-yield purification of an organic solvent-tolerant lipase from Pseudomonas sp. strain S5, Annalytical Biochemistry, vol. 341, 2005, p. 267-274.

[22] Atlas, R.M., Petroleum microbiology, Macmillan Publishing Company, New York, 1984.

[23] Schnoor, J.L., Licht, L.A., McCutcheon, S.C., Wolfe, N.L., Carreira, L.H., Phytoremediation of organic and nutrient contaminants, Environmental Science and Technology, vol. 29, no. 7, 1995, p. 318A-323A.

[24] Baker, K.H., Herson, D.S., Bioremediation, McGraw-Hill, New York, 1994.

[25] Bartha, R., Bossert, I., The treatment and disposal of petroleum wastes, In: R. M. Atlas (eds). Petroleum Microbiology, Macmillan, New York, 1984. 